\title{
ОСОБЛИВОСТІ ХАРЧОВОЇ ПОВЕДІНКИ ХВОРИХ НА АЛІМЕНТАРНЕ ОЖИРІННЯ ТА РОЛЬ МЕДИЧНОЇ СЕСТРИ У ЇЇ КОРЕКЦІї
}

\author{
М. С. Люблінська, І. В. Пірус, В. А. Мусієнко, А. І. Ціпкало, М. I. Марущак \\ ДВНЗ «Тернопільський державний медичний університет \\ імені І. Я. Горбачевського МОЗ Украӥни»
}

\begin{abstract}
У статті наведено дані про особливості стилю харчування хворих на аліментарне ожиріння I-II ступенів тяжкості. Встановлено, що серед етіологічних факторів ожиріння домінують часте споживання їжі, переважно у вечірній час, збільшення частки вуглеводів у їжі та заміна здорової їжі на фаст-фуд у поєднанні 3 тютюнокурінням і вживанням алкоголю. Роль медичної сестри полягає в організації і проведенні освітньої роботи із модифікації стилю харчування та із профілактики тютюнокуріння і вживання алкоголю.
\end{abstract}

\section{PECULIARITIES OF FEED BEHAVIOR OF PATIENTS WITH ALIMENTARY OBESITY AND THE ROLE OF NURSE IN ITS CORRECTION}

\author{
M. S. Lublinska, I. V. Pirus, V. A. Musienko, A. I. Tsipkalo, M. I. Marushchak
}

\section{Horbachevsky Ternopil State Medical University}

\begin{abstract}
The article presents data on the nutritional style of patients with alimentary obesity I-II stage. It has been established that among the etiological factors of obesity frequent food intake, mainly in the evening, is dominated by increased carbohydrate intake and the replacement of healthy food in fastfood in combination with tobacco and alcohol use. The role of the nurse is to organize and conduct educational work on the modification of the nutrition style and on the prevention of tobacco smoking and the use of alcohol.
\end{abstract}

Вступ. Зростання відсотка таких захворювань, як цукровий діабет 2 типу, ішемічна хвороба серця, гіпертензія і деяких форм раку змушує багатьох науковців загострювати нашу увагу на надлишковій масі тіла й ожирінні [1, 2]. На нашій планеті кожна четверта людина має надлишкову масу тіла, а аліментарне ожиріння набуває масштабів епідемії XXI століття [3, 4]. Актуальність проблеми ожиріння полягає ще і в тому, що кількість людей з надлишковою масою тіла прогресивно збільшується, за кожні десять років на $10 \%$ [5]. Потрібно зазначити, що помірне ожиріння зменшує тривалість життя в середньому на 3-5 років, виражене - до 15 років [5]. Близько 250 млн людей на Землі хворіють на ожиріння, індекс маси тіла яких більше 30 кг/м², а понад 500 млн людей мають надлишкову масу з індексом маси тіла 25,0-29,9кг/м² [6]. Дані окремих авторів вказують, що надлишкову масу тіла у світі мають близько 1,7 млрд осіб, з яких на ожиріння хворіють 320 млн, а в Європі ці показники становлять 400 млн та 130 млн відповідно [7]. X. Formiguera вказує, що ця цифра може подвоїтися до 2025 р., якщо не буде вжито жодних заходів у напрямку профілактики надлишкової маси тіла [8].

До факторів, які визначають розвиток ожиріння, належать: генетичні, демографічні (вік, стать, етнічна приналежність), соціально-економічні (освіта, професія, сімейний стан), психологічні (перенапруження нервової системи), поведінкові (харчування, фізична активність, алкоголь, куріння, стреси). Особливу увагу на даний час приділяють раціону харчування та фізичній активності. Відповідно до останніх рекомендацій експертів ВООЗ/ФАО, акцентують увагу на необхідності зниження споживання енергії за рахунок жирів, особливо насичених і трансжирних кислот, а заміщення їх у раціонах на ненасичені; обмеження споживання моно-, ди- і полісахаридів у періоди життя не пов'язані зі значними фізичними навантаженнями [9]. Такі рекомендації слугують орієнтирами національної політики в галузі харчування, освітніх програм із питань харчування та інших заходів. Одна з проблем, яка постає перед медичним персоналом, - це покращення якості діагностики та профілактики аліментарного ожиріння.

() М. С. Люблінська, І. В. Пірус, В. А. Мусієнко, А. І. Ціпкало, М. І. Марущак, 2019 
Метою дослідження було проаналізувати особливості стилю харчування хворих на аліментарне ожиріння I-ІІ ступенів тяжкості.

Основна частина. У дослідження було включено 74 особи чоловічої статі віком $(42,4 \pm 2,3)$ року, з них ожиріння діагностовано у 54 пацієнтів (28 - І ступеня, 26 - ІІ ступеня) та 20 осіб із нормальною масою тіла (контрольна група). Ожиріння визначали за індексом маси тіла (Кетле) за формулою: IMT = маса тіла (кг) / зріст $\left(\mathrm{M}^{2}\right)$. Якщо ІМТ становив 18,5-24,9 кг/м², то це вважали нормальною масою тіла, 30 кг/м² та більше ожиріння (І ступеня при ІМТ 30,0-34,9 кг/м²; ІІ ступеня при ІМТ 35,0-39,9 кг/м²). Усім респондентам, які були включені у дослідження, провели анкетування. Опитування хворих проводили у весняний період за опитувальником М. Аравіцької [10], розроблений на основі рекомендації програми профілактики неінфекційних захворювань CINDI, присвячений особливостям стилю та характеру харчування, шкідливим звичкам, виявленню причин неефективності дієтотерапії.

При аналізі особливостей стилю харчування встановлено порушення стереотипу харчування у хворих на ожиріння. Так, встановлено, що пацієнти з ожирінням I ступеня харчуються 3-4 рази на добу, переважно в обід, для приготування їжі використовують будь-які жири. У харчовий раціон пацієнти 3 ожирінням I ступеня переважно включають декілька разів на тиждень свіжі овочі та фрукти, солодощі, 4-6 разів на тиждень - фаст-фуд. Варто відзначити, що більшість таких пацієнтів надмірно не споживають сіль, не курять, в середньому один раз на тиждень вживають алкоголь (табл. 1). Якщо зіставити отримані дані з результатами контрольної групи, то основна роль медичної сестри у профілактичній роботі з пацієнтами цієї категорії повинна бути спрямована на зменшення прийомів й основного об'єму їжі у вечірній час, зменшення частки вуглеводів у їжі та частоти споживання фаст-фуду.

Аналіз стилю харчування хворих на ожиріння II ступеня свідчить про те, що вони харчуються 3-4 рази на добу, переважно в обід, для приготування їжі використовують будь-які жири. У харчовий раціон пацієнти з ожирінням І ступеня включають декілька разів на тиждень свіжі овочі та фрукти, 4-6 разів на тиждень солодощі й фаст-фуд. Варто відзначити, що більшість таких пацієнтів надмірно споживають сіль, курять, в середньому 2-3 рази на тиждень вживають алкоголь (табл. 1). Якщо зіставити отримані дані з результатами контрольної групи, то основна роль медичної сестри у профілактичній роботі з пацієнтами цієї категорії повинна бути спрямована на зменшення прийомів й основного об'єму їжі у вечірній час, зменшення частки вуглеводів у їжі та частоти споживання фастфуду, боротьба зі шкідливими звичками (алкоголь, тютюнокуріння, надмірне споживання солі).

Аналіз отриманих даних вказує на те, що зі зростанням IMT у пацієнтів зростає частота прийому їжі (з 15,0 у контрольній групі до 30,8 \% у хворих на ожиріння II ступеня), при цьому зростає споживання у вечірній час (з 15,0 до 35,7 \% відповідно). Респонденти, включені у дослідження, здебільшого не звертали увагу на жири, які використовували у приготуванні їжі. Варто також відзначити, що зростання IMT у пацієнтів асоціювалося з динамічним зменшенням споживання свіжих овочів та фруктів та збільшенням у раціоні вуглеводів (солодощів і кількості цукру), зростанням частоти споживання фаст-фуду.

Визначальними серед факторів ожиріння вважають переїдання, надмірне споживання жирної їжі, що підтверджено результатами нашого дослідження, у поєднанні з низькою фізичною активністю, що в осіб зі спадковою схильністю призводить до розвитку цього захворювання [11].

Важливе значення у регуляції маси тіла має склад і набір продуктів харчового раціону. Різні маркетингові дослідження підтверджують, що борошняні вироби, жирне м'ясо, ковбаси та сосиски, їжа швидкого приготування все більше витісняють з раціону українців овочі та фрукти. Українці часто їдять шкідливу їжу гамбургери, чіпси, шоколадні батончики тощо, які $\epsilon$ дуже калорійними та розвивають харчову залежність. Незважаючи на те, що вже ніби наситився, але вже через годину голод мучить знову, а маса тіла від такої їжі постійно збільшується [12].

До переїдання призводить нерегулярне харчування. Нечасте споживання їжі спричиняє збільшення маси, тоді як більш часте - зменшення. Це насамперед стосується людей, які у зв'язку з умовами праці основну масу їжі споживають ввечері, після роботи. Це викликає надмірний апетит і обов'язково - переїдання. Під час сну після калорійної їжі витрачається дуже мало енергії, і харчові речовини відкладаються у вигляді жиру в жировій тканині, що й призводить врешті до ожиріння з усіма його наслідками [13].

Депресія, заклопотаність, дратівливість також часто призводять до переїдання. Ці стани розвиваються внаслідок низького вмісту серотоніну в мозку. Низький його вміст істотно впливає на потяг до со- 
Таблиця 1. Особливості стилю харчування хворих на ожиріння

\begin{tabular}{|c|c|c|c|}
\hline \multirow{2}{*}{ Особливості харчування } & \multirow{2}{*}{$\begin{array}{c}\text { Контрольна група } \\
(\mathrm{n}=20)\end{array}$} & \multicolumn{2}{|c|}{ Пацієнти з ожирінням } \\
\hline & & І ступеня $(\mathrm{n}=28)$ & ІІ ступеня $(\mathrm{n}=26)$ \\
\hline \multicolumn{4}{|l|}{ Частота харчування на добу: } \\
\hline один раз & $1(5 \%)$ & $1(3,6 \%)$ & 0 \\
\hline 2 рази & $5(25 \%)$ & $7(28 \%)$ & $4(15,4 \%)$ \\
\hline 3-4 рази & $11(55 \%)$ & $14(54 \%)$ & $14(53,8 \%)$ \\
\hline більше ніж чотири рази & $3(15 \%)$ & $5(17,9 \%)$ & $8(30,8 \%)$ \\
\hline \multicolumn{4}{|l|}{ Переважне споживання їжі: } \\
\hline зранку & $8(40 \%)$ & $5(17,9 \%)$ & $2(7,7 \%)$ \\
\hline в обід & $9(45 \%)$ & $15(53,6 \%)$ & $14(53,8 \%)$ \\
\hline ввечері & $3(15 \%)$ & $8(28,6 \%)$ & $10(35,7 \%)$ \\
\hline \multicolumn{4}{|c|}{ Використання жирів для приготування їжі: } \\
\hline переважно тваринні & $1(5 \%)$ & $3(10,7 \%)$ & $4(15,4 \%)$ \\
\hline переважно рослинні & $9(45 \%)$ & $4(14,3 \%)$ & $3(11,5 \%)$ \\
\hline без жирів & $2(10 \%)$ & 0 & 0 \\
\hline будь-які & $8(40 \%)$ & $11(39,3 \%)$ & $19(73,1 \%)$ \\
\hline \multicolumn{4}{|l|}{ Надмірне споживання солі: } \\
\hline так & $3(15 \%)$ & $10(35,7 \%)$ & $16(61,5 \%)$ \\
\hline $\mathrm{Hi}$ & $17(85 \%)$ & $18(64,3 \%)$ & $10(35,7 \%)$ \\
\hline \multicolumn{4}{|l|}{ Споживання свіжих овочів та фруктів: } \\
\hline один раз на тиждень & $2(10 \%)$ & $5(17,9 \%)$ & $8(30,8 \%)$ \\
\hline декілька разів на тиждень & $10(50 \%)$ & $7(28,0 \%)$ & $10(35,7 \%)$ \\
\hline щодня & $8(40 \%)$ & $6(21,4 \%)$ & $8(30,8 \%)$ \\
\hline \multicolumn{4}{|l|}{ Частота споживання солодощів: } \\
\hline щодня & $1(5 \%)$ & $4(14,3 \%)$ & $6(23,1 \%)$ \\
\hline 4-6 разів на тиждень & $7(35 \%)$ & $13(46,4 \%)$ & $13(50,0 \%)$ \\
\hline 2-3 рази на тиждень & $10(50 \%)$ & $10(35,7 \%)$ & $7(26,9 \%)$ \\
\hline не вживаю & $2(10 \%)$ & $1(3,6 \%)$ & 0 \\
\hline \multicolumn{4}{|l|}{ Кількість чайних ложок цукру на добу: } \\
\hline не вживаю & $4(20 \%)$ & 0 & 0 \\
\hline вживаю цукрозамінник & $3(15 \%)$ & 0 & 0 \\
\hline до 4 ложок & $11(55 \%)$ & $9(32,1 \%)$ & $5(19,2 \%)$ \\
\hline 4-8 ложок & $2(10 \%)$ & $10(35,7 \%)$ & $10(35,7 \%)$ \\
\hline більше 8 ложок & 0 & $9(32,1 \%)$ & $11(42,3 \%)$ \\
\hline \multicolumn{4}{|l|}{ Частота споживання фаст-фуду: } \\
\hline щодня & 0 & $3(10,7 \%)$ & $5(19,2 \%)$ \\
\hline 4-6 разів на тиждень & $2(10 \%)$ & $15(53,6 \%)$ & $13(50,0 \%)$ \\
\hline 2-3 рази на тиждень & $10(50 \%)$ & $10(35,7 \%)$ & $6(23,1 \%)$ \\
\hline не вживаю & $8(40 \%)$ & 0 & 0 \\
\hline \multicolumn{4}{|l|}{ Частота вживання алкогольних напоїв: } \\
\hline ніколи & $3(15 \%)$ & $1(3,6 \%)$ & 0 \\
\hline один раз на місяць & $13(65 \%)$ & $8(28,6 \%)$ & $1(3,8 \%)$ \\
\hline один раз на тиждень & $3(15 \%)$ & $11(39,3 \%)$ & $8(30,8 \%)$ \\
\hline 2-3 рази на тиждень & $1(5 \%)$ & $5(17,9 \%)$ & $11(42,3 \%)$ \\
\hline щодня & 0 & $3(10,7 \%)$ & $6(23,1 \%)$ \\
\hline \multicolumn{4}{|l|}{ Куріння на даний момент: } \\
\hline так & $3(15 \%)$ & $11(39,3 \%)$ & $15(57,7 \%)$ \\
\hline $\mathrm{Hi}$ & $17(85 \%)$ & $17(60,7 \%)$ & $11(42,3 \%)$ \\
\hline
\end{tabular}

лодкого, борошняних і крохмалевмісних страв. Таким чином, пригнічений настрій спричиняє «переїдання солодощами», а насичення ними - до задоволення і комфортного стану [14].
Дослідники університету Наварра в Іспанії довели, що куріння може викликати в людей ожиріння, водночас штучно може стримувати набирання маси, та коли людина кидає курити, то стрімко збільшується 
маса тіла. Відчуття голоду при курінні може бути викликано активізацією роботи серцево-судинної системи через звуження судин, яка насамперед провокує викид енергії та їі витрату. Нікотин також діє і на шлунок, викликаючи збільшення секреції шлункового соку. Це призводить до посилення роботи травлення і викликає відчуття, що весь час хочеться їсти. Можливою причиною відчуття голоду $\epsilon$ і стрес, оскільки це умовний рефлекс, і напруження, пов'язане з ним, часто знімається «заїданням» неприємностей і штучним розслабленням за допомогою нікотину. Всі ці реакції організму спричиняють збільшення маси тіла та ожиріння [15].

Дослідники не встановили причинно-наслідковий зв'язок між вживанням алкоголю і збільшенням маси тіла, зазначаючи, що вживання алкогольних напоїв у малих дозах не призводить до зростання жирової маси. Разом із цим, відзначають, що в разі споживання алкоголю у великих дозах, організм уповільнює

\section{СПИСОК ЛІТЕРАТУРИ}

1. Kopelman P. G. Obesity as a medical problem / P. G. Kopelman // Nature. - 2000. - No. 404(6778). - P. 635-643.

2. Luchsinger J. A. A Work in progress: The metabolic syndrome / J. A. Luchsinger // Sci. Agin. Knowl. Environ J. 2006. - Р. 10-19.

3. Иващенко И. Н. Исследование механизмов терморегуляции детей и подростков с метаболическим синдромом / И. Н. Иващенко // Научный журнал КубГАУ. 2014. - № 96 (02). - С. 1-10.

4. Панкрушина А. Н. Лептин: новые перспективы и подходы к коррекции ожирения / А. Н. Панкрушина, К. Ю. Толстых // Вестник ТвГУ. Серия «Биология и экология». - 2008. - Вып. 10. - С. 91-97.

5. Малкина-Пых И. Г. Исследование влияния индивидуально-психологических характеристик на результаты коррекции пищевого поведения и алиментарного ожирения / И. Г. Малкина-Пых // Сибирский психологический журнал. - 2008. - № 30. - С. 90-94.

6. Корниенко Е. А. Ожирение и кишечная микробиота: современная концепция взаимосвязи / Е. А. Корниенко, О. К. Нетребенко // Педиатрия. - 2012. - Т. 91, № 2. C. $110-122$.

7. Москаленко В. Ф. Формування глобальної комплексної інтегральної міжсекторальної системи профілактики - інноваційний підхід до вирішення сучасних проблем громадського здоров'я (огляд літератури та власних досліджень) / В. Ф. Москаленко // Журнал АМН України. 2009. - Т. 15, № 3. - С. 516-542. метаболізм, припиняє спалювати накопичений жир, вважаючи за краще отримувати енергію з власних м'язів. Отже, м'язова маса знижується, а жировий прошарок збільшується [16].

Тому, в програмі профілактики з ожирінням повинна бути включена освітня робота медичного персоналу із модифікації стилю харчування. Враховуючи динамічне зростання частоти вживання алкоголю й тютюнокуріння, медична сестра повинна проводити бесіди з пацієнтами з ожирінням про наслідки цих шкідливих звичок на здоров'я людини.

Висновки. Серед етіологічних факторів ожиріння домінують часте споживання їжі, переважно у вечірній час, збільшення частки вуглеводів у їжі та заміна здорової їжі на фаст-фуд у поєднанні з тютюнокурінням і вживанням алкоголю.

Роль медичної сестри полягає в організації і проведенні освітньої роботи із модифікації стилю харчування та із профілактики тютюнокуріння і вживання алкоголю.

8. Formiguera X. Obesity: epidemiology and clinical aspects / X. Formiguera, A. Cantón // Best Pract. Res. Clin. Gastroenterol. - 2004. - No. 18 (6). - Р. 1125-1146.

9. Рацион, питание и предупреждение хронических заболеваний. Доклад совместного консультативного совещания экспертов ВОЗ/ФАО. - 2003. - 208 с.

10. Аравіцька М. Особливості стилю життя хворих на ожиріння І-ІІІ ступеня / М. Аравіцька // Молода спортивна наука України. - 2015. - Т. 3. - С. 6-10.

11. Бондар П. М. Метаболічний синдром / П. М. Бондар // Лікування та діагностика. - 2001. - № 4. - С. 24-29.

12. Каминский А. В. Методы коррекции избыточной массы тела и ожирения / А. В. Каминский // Здоровье Украины. - 2005. - № 3. - С. 17-18.

13. Абдоминальное ожирение: клинико-социальные аспекты проблемы / В. Б. Гриневич, Е. И. Сас, Ю. А. Кравчук, О. И. Ефимов // Фарматека. - 2012. - № 16. - С. 29-34.

14. Dixon J. B. Assessment of obesity and its associated comorbidities / J. B. Dixon // Obesity reviews. - 2006. - Vol. 7, Suppl. 2. - P. 2.

15. Вчені з'ясували, чому курці багато їдять [Електронний ресурс]. - 2018. - Режим доступу : https://ukr. segodnya.ua/lifestyle/wellness/uchenye-vyyasnili-pochemukurilshchiki-mnogo-edyat-1128719.html.

16. Експерти розповіли, чи призводить вживання алкоголю до ожиріння [Електронний ресурс]. - 2018. - Режим доступу : https://www.unn.com.ua/uk/news/1743575eksperti-rozpovili-chi-prizvodit-vzhivannya-alkogolyu-doozhirinnya. 